BUILDING, PLANNING AND DEVELOPMENT 
Advanced Building Quantities

Building Economics

Building Maintenance

Building Technology

Building Quantities Explained

Computers in Quantity Surveying

Introduction to Valuation

National and Local Taxation

The British Construction Industry: an introduction
Ivor H. Seeley and R. Winfield

Ivor H. Seeley

Ivor H. Seeley

Ivor H. Seeley

Ivor H. Seeley

R. J. Alvey

D. Richmond

Michael Rayner

Dennis F. Dolan

P. N. Balchin and J. L. Kieve

Related Macmillan Titles

Administrative Law for the Construction Industry

J. R. Lewis

Law for the Construction Industry

J. R. Lewis 


\section{BUILDING, PLANNING AND DEVELOPMENT}

\section{ERNEST H. GREEN, F.R.I.C.S., F.I.A.S., F.R.V.A.}

Consultant and External Tutor, College of Estate Management, one time Principal Lecturer and Deputy Head of Department of Professional Studies, West London College 
(C) Ernest H. Green 1981

Softcover reprint of the hardcover 1st edition 1981

All rights reserved. No part of this publication may be reproduced or transmitted, in any form or by any means, without permission.

First published 1981 by

THE MACMILLAN PRESS LTD

London and Basingstoke

Associated companies in Delhi Dublin

Hong Kong Johannesburg Lagos Melbourne

New York Singapore and Tokyo

\section{British Library Cataloguing in Publication Data}

Green, Ernest $\mathrm{H}$

Building planning and development. -(Macmillan

building and surveying series).

1. Real estate development - England

I. Title

$333.3^{\prime} 8$

HD608

ISBN 978-0-333-19789-9 ISBN 978-1-349-16535-3 (eBook)

DOI 10.1007/978-1-349-16535-3

This book is sold subject to the standard conditions of the Net Book Agreement.

The paperback edition of this book is sold subject to the condition that it shall not, by way of trade or otherwise, be lent, resold, hired out, or otherwise circulated without the publisher's prior consent in any form of binding or cover other than that in which it is published and without a similar condition including this condition being imposed on the subsequent purchaser. 


\section{CONTENTS}

Preface

vii

1. Introduction-an Historical Approach 1

2. Parties to a Development 15

3. Receiving Instructions and Preliminary Investigations 20

4. Land Use and Its Control 28

5. Site Appraisal and Analysis 34

6. The Economic Approach to Development 42

$\begin{array}{lr}\text { 7. Roads, Streets and Footpaths } & 50\end{array}$

8. Residential Development $\quad 59$

$\begin{array}{lr}\text { 9. Community Development } & 81\end{array}$

$\begin{array}{lr}\text { 10. Shop Development } & 87\end{array}$

11. Town Centre Development and Renewal 101

$\begin{array}{lr}\text { 12. Industrial Development } & 118\end{array}$

$\begin{array}{lr}\text { 13. Services } & 143\end{array}$

14. Landscaping 153

Appendix A Use Classes Order, 1972

$\begin{array}{ll}\text { Appendix } B \text { Control Legislation } & 160\end{array}$

$\begin{array}{ll}\text { Appendix C A Developer's Brief } & 162\end{array}$

Appendix $D$ Outline of Procedure from the Street
Works Code, 1892

$\begin{array}{lll}\text { Appendix } E & \text { A Summary of the Advance Payments Code } & \\ \text { (Highways Act, 1959) } & 168\end{array}$

$\begin{array}{ll}\text { Appendix } F \text { Arndale Chronology } & 169\end{array}$ 
Appendix $G$ Trees in Landscaping

Index 


\section{PREFACE}

This textbook is intended primarily for students who are in the final stages of their studies for a degree or professional qualification in one of the landed professions. The author makes no attempt to follow the exact syllabus of any particular body because they are often subject to change, but hopes that the book will be of value to many.

A large development demands many skills and professional specialisations and no one person could be equipped to deal with all the stages in the development process. It is important nevertheless for all those taking part to have at least an understanding of the contributions made by others.

Each chapter deals with a different aspect of the development process and each, if studied in isolation, could be shown to be incomplete-but that is inevitable with a book of this kind.

It will not teach any particular member of a development team his job but it should enable him to see a development scheme in a wider perspective and this in turn should make each individual contribution more valuable.

This book is written at a time when little development is taking place, at least by comparison with the boom period of the late 1960s and early 1970s. Building costs have virtually doubled in the past few years and interest rates have been high. This has made it more costly to borrow money and it has also meant that the return in the form of rent on new development has to be proportionately higher than was generally acceptable a few years ago.

The author is conscious of this situation and therefore appreciates that some of the material used in dealing with the financial aspects of development may not be strictly applicable to conditions as they exist today, but in order to produce a balanced textbook it is necessary to assume reasonably stable conditions, and it is hoped that these will prevail when the book is in circulation. 


\section{ACKNOWLEDGEMENTS}

I am grateful to Ian Hamilton-Penney, M.S.A.A.T., A.I.P.D., for most of the illustrations used in the book, and to Ken Blount, F.I.A.S., M.I.L.G.A., A.M.B.I.M., Chief Building Surveyor for Wolverhampton Borough Council, for his guidance on building control.

I also wish formally to acknowledge the help given to me by: Town and City Properties Ltd on my visits to the Arndale Centre at Luton; and The Bradford Property Trust, for plans and other information on the development of a new village at Martlesham Heath near Ipswich.

E.H.G. 